DOI: $10.34220 /$ issn.2222-7962/2020.1/2

УДК $630 * 228.7$

$$
\begin{gathered}
\text { ДИНАМИКА РАНГОВОГО РАСПРЕДЕЛЕНИЯ ДЕРЕВЬЕВ ПО ВЫСОТЕ } \\
\text { В ПОЛЕЗАЩИТНОЙ ПОЛОСЕ С УЧАСТИЕМ ДУБА ЧЕРЕШЧАТОГО (QUERCUS ROBUR L.) } \\
\text { И КЛЁНА ОСТРОЛИСТНОГО (ACER PLATANOIDES L.) }
\end{gathered}
$$

\author{
кандидат биологических наук, доцент О.В. Грибачева ${ }^{1}$ \\ доктор сельскохозяйственных наук, профессор А.И. Чернодубов² \\ магистрант Д.В. Сотников ${ }^{1}$ \\ 1 - Государственное образовательное учреждение Луганской Народной Республики \\ «Луганский национальный аграрный университет», г. Луганск, Луганская Народная Республика \\ 2 - ФГБОУ ВО «Воронежский государственный лесотехнический университет имени Г.Ф. Морозова», \\ г. Воронеж, Российская Федерация
}

Организующей основой адаптивно-ландшафтного земледелия является защитное лесоразведение. Цель работы - осуществить распределение деревьев дуба черешчатого (Quercus robur L.) и клёна остролистного (Acer platanoides L.) по высоте для установления сложности структуры древостоя. Рассмотрена дифференциация деревьев по высоте в полезащитной полосе, которая расположена в окрестностях с. Золотарёвка, Луганская область, Станично-Луганский район. В исследуемом насаждении нами были заложены две постоянные пробные площадки в соответствии с ОСТ 56-69-83. По результатам перечислительной таксации определяли относительную высоту каждого класса ранжированного ряда, редукционные числа и ранги древостоев клёна остролистного и дуба черешчатого, образующих полезащитную полосу. Редукционные числа и ранги определяли по методике Л.В. Стоноженко и др. Авторами выявлено, что преобладание деревьев-лидеров с ранговым классом 26-27 в древостое дуба черешчатого (Quercus robur L.) на первой пробной площадке объясняется снижением интенсивности роста основной части древостоя вследствие разреженного стояния деревьев. Анализируя состояние древостоя, выяснили, что при формировании второго яруса в древостое из клёна остролистного на первой пробной площадке происходит ухудшение роста и развития дуба черешчатого и, как конечный результат, его разреживание. Особое внимание в работе авторы акцентируют на том, что при упрощении древостоя клёна остролистного на второй пробной площадке происходит улучшение роста и развития дуба черешчатого и, как следствие, усложнение формы насаждения.

Ключевые слова: полезащитная полоса, Quercus robur L., Acer platanoides L., древостой, ранжированный ряд по высоте, относительная средняя высота рангового класса, редукционные числа, редукционные ранги 


\title{
DYNAMICS OF HEIGHT RANGE DISTRIBUTION OF TREES IN THE FOREST SHELTER BELT WITH PARTICIPATION OF ENGLISH OAK (QUERCUS ROBUR L.) AND NORWAY MAPLE (ACER PLATANOIDES L.)
}

\author{
$\mathrm{PhD}$ (Biology), Associate professor O.V. Gribacheva ${ }^{1}$ \\ DSc (Agriculture), Professor A.I. Chernodubov ${ }^{2}$ \\ Master's degree student D.V. Sotnikov ${ }^{1}$ \\ 1 - State Educational Institution of the Lugansk People's Republic "Lugansk National Agrarian University", \\ Lugansk, Lugansk People's Republic \\ 2 - FSBEI HE "Voronezh State University of Forestry and Technologies named after G.F. Morozov", \\ Voronezh, Russian Federation
}

\begin{abstract}
Protective afforestation is organizing basis of adaptive landscape agriculture. The aim of the study is to distribute the trees of English oak (Quercus robur L.) and Norway maple (Acer platanoides L.) in height to establish the complexity of stand structure. The differentiation of trees by height in the shelterbelt, which is located in the vicinity of the village Zolotarevka, Lugansk region, Stanichno-Lugansk district, has been considered. In the plantation under study, we laid two permanent test plots in accordance with 56-69-83 Industrial Standard. Relative height of each class of the ranked row, reduction numbers and ranks of maple and oak stands, forming a field-protecting strip, have been determined based on the results of enumeration taxation. Reduction numbers and ranks have been determined according to the methodology of L.V. Stonozhenko et al. The authors have revealed that the predominance of leader trees with 26-27 grades in the oak-tree stand of Quercus robur L. (first test plot) is explained by a decrease in the growth rate of the main part of the stand due to the sparse standing of trees. Analyzing the state of the stand, during the formation of the second tier (maple stand on the first test plot), growth and development of oak and is worsened. Thinning can be seen as the final result. The authors emphasize in the work that there is an improvement in the growth and development of English oak when simplifying maple stand (second test plot). The consequence of all these is more complicated form of plantation.
\end{abstract}

Keywords: forest shelter belt, Quercus robur L., Acer platanoides L., stand, height ranked row, relative average height of rank class, reduction numbers, reduction ranks

\section{Введение}

Организующей основой адаптивноландшафтного земледелия является защитное лесоразведение. Защитные лесные насаждения преобразуют условия местопроизрастания и прилегающих к ним территорий, которые сами по себе являются динамичными, постоянно изменяющимися с возрастом насаждениями. При этом оптимальные мелиоративные функции выполняют насаждения, имеющие хороший рост и состояние. Однако в последнее десятилетие в лесоаграрных ландшафтах всё большую актуальность приобретает проблема ухудшения состояния и сохранности защитных лесных насаждений, утраты ими защитномелиорирующих функций по причине отсутствия их лесохозяйственного обслуживания $[16,17,18]$. Полезащитные лесные насаждения даже на не-

больших территориях, прилегающих к населённым пунктам, возле которых интенсивно ведётся сельское хозяйство, способствуют уменьшению числа засух, прекращению снижения уровня грунтовых вод. Структура древостоя в основном определяет всю ценотическую структуру лесного фитоценоза. Известно, что строение древостоев в процессе их роста заметно изменяется. На строение древостоя оказывают влияние такие факторы, как густота, возрастная и пространственная структура древостоя. Динамика рядов распределения числа стволов по высоте обусловлена текущим приростом, изменением их рангов в процессе прироста и отпадом части деревьев [9]. Закономерности строения насаждений по высоте и диаметру изучали $[1,3,4,8,14$, $15,18,19,20,21,22,23,24]$. Цель работы - осуще- 


\section{Природопользование}

ствить распределение деревьев дуба черешчатого (Quercus robur L.) и клёна остролистного (Acer platanoides L.) по высоте и группам ранговых коэффициентов (редукционным числам).

\section{Материалы и методы}

Полезащитная полоса, пространственную структуру которой изучали, расположена в окрестностях с. Золотарёвка (в 65 километрах от города Луганска). Территория, на которой произрастает исследуемая полезащитная полоса, относится к шестому агролесомелиоративному району Украины по Б.И. Логгинову [5]. Почвы района - неглубокие с укороченным профилем, малогумусные обыкновенные чернозёмы. Этот район относится к наиболее подверженным суховеям территориям, где количество дней с суховеями достигает 16-24, а в отдельные годы - даже 60. Преобладающее направление ветра при суховеях восточное и юговосточное. Рекомендованное направление продольных полос ССВ-ЮЮЗ. В исследуемом насаждении нами были заложены постоянные пробные площадки в соответствии с ОСТ 56-69-83 [12]. При ревизии постоянных пробных площадок были использованы геоботанические и общепринятые лесоводственные методики [13]. На этих площадках неоднократно производился перечёт древостоя, выявлялось видовое разнообразие, учитывался подрост. На первой пробной площадке было изучено 40 деревьев клёна остролистного и 42 дерева дуба черешчатого, а на второй - 50 деревьев клёна остролистного и 32 дерева дуба черешчатого. Деревья отбирались по методу случайной выборки из всех ступеней толщины. Математическую обработку результатов исследований проводили по методике Б.А. Доспехова [6]. Высоту деревьев измеряли при помощи оптического высотомера ЭВ-1. Для анализа высотного строения использовали показатель строения - редукционные числа по высоте (Rh), вычисляемые по аналогии с методикой К.К. Высоцкого [4] для нахождения редукционных чисел по диаметру в редакции С.А. Короткова [8]. В соответствии с этой методикой производили расчёт показателя $\Delta \mathrm{Rh}$ как разницы относительной высоты первого и десятого классов. Расчёт редукционных чисел производили по следующей методике:
- построение ранжированного ряда по высотам от минимальной до максимальной;

- разделение полученного ряда на 10 классов;

- определение средней высоты каждого класса hср (n);

- определение относительной высоты каждого класса по формуле $\mathrm{R}_{\mathrm{h}}(\mathrm{n})=\mathrm{hcp}(\mathrm{n}) / \mathrm{hcp}(6)$; - определение разницы $\Delta \mathrm{R}_{\mathrm{h}}=\mathrm{R}_{\mathrm{h}}(10)-\mathrm{R}_{\mathrm{h}}(1)$.

Для древостоев клёна остролистного на пробных площадках значение высоты деревьев ниже 7 м в расчёт не брались, а для деревьев дуба черешчатого - ниже 6 м. Показатель $\Delta \mathrm{R}_{\mathrm{h}}$ наиболее достоверно отражает зависимость значений показателя $\Delta \mathrm{R}_{\mathrm{h}}$ от формы древостоя, так как значения редукционных чисел являются средними значениями в классе и единичные деревья, сильно отличающиеся по высоте от других деревьев, в древостое не оказывают значительное влияние на увеличение показателя $\Delta \mathrm{R}_{\mathrm{h}}$.

Первая и вторая пробные площадки представлены дубом черешчатым и клёном остролистным. Дуб черешчатый (Quercus robur L.) занимает три центральных ряда, а клён остролистный (Acer platanoides L.) - два крайних ряда. Дуб высевали гнездовым способом с последующим вводом сопутствующих и быстрорастущих пород. Размеры прямоугольных площадок составляют: первой 1170 м $^{2}$, а второй - 1502,8 м². Конструкция полезащитной полосы - ажурно-продуваемая. Состав насаждения - 6Дч4Кло. Кустарниковый ярус представлен тёрном колючим (Prunus spinosa L.). Выявлен в небольшом количестве семенной и вегетативный подрост дуба черешчатого. Тип лесорастительных условий - сухая клёновая дубрава $\left(\mathrm{D}_{1}\right)$. Полнота насаждения - 0,5-0,6. Тип почвы - обыкновенные чернозёмы.

Высота дерева связана с положением его в насаждении. Связь эта характеризуется редукционными числами по высоте [9]. Закономерности строения насаждений по высоте и диаметру изучались многими учёными России и за рубежом $[8,10$, $11,14,15]$. В лесах Белоруссии ранги по высоте были изучены В.Ф. Багинским [2]. По его данным ранги по высоте от наименьшего до наибольшего дерева изменяются от 0,6 до 1,25 и даже до 1,30 . На 


\section{Природопользование}

постоянных пробных площадках Щелковского учебно-опытного лесхоза Московской области Л.В. Стоноженко и др. определили значение $\Delta \mathrm{R}_{\mathrm{h}}$ для простых древостоев - 0,418-0,573, а для сложных - 0,583-1,283 [15]. Ими отмечено, что смешанные многоярусные древостои больше отвечают целям ведения хозяйства в защитных лесах.

\section{Результаты и обсуждение}

В древостое клёна остролистного на первой пробной площадке наибольшее количество деревьев (10 шт., или 25,0\%) наблюдается в ранговом классе, где высота их достигает 25 м (табл. 1). На второй пробной площадке наблюдается смещение количественного максимума в сторону рангового класса, где высота деревьев достигает 14-15 м. По результатам наблюдений в древостое дуба черешчатого на первой пробной площадке разбег в ранговых классах по высоте достигает от 7 м до 29 м (табл. 2).
Соотношение деревьев дуба черешчатого с высотой от 26 м до 27 м в древостое на второй пробной площадке по сравнению с первой пробной площадкой составляет 1:15. Преобладание деревьев-лидеров с ранговым классом 26-27 в древостое на первой пробной площадке объясняется снижением интенсивности роста основной части древостоя вследствие разреженного стояния деревьев. Наибольшая представленность деревьев различных ранговых классов по высоте наблюдается в древостое дуба черешчатого на второй пробной площадке.

Ранговое положение каждого дерева оценивали редукционным числом (ранговым коэффициентом). Деревья распределяли по классам редукционных чисел. Редукционные числа и ранги по высоте для древостоя клёна остролистного (Acer platanoides L.) на постоянных пробных площадках представлены на рис. 1a, 16.

Таблица 1

Количественное соотношение деревьев клёна остролистного (Acer platanoides L.) по ранговым классам высот в полезащитной полосе

\begin{tabular}{|c|c|c|c|c|c|c|c|c|c|c|c|}
\hline \multirow[b]{2}{*}{ Название породы } & \multirow{2}{*}{$\begin{array}{l}\text { Общее } \\
\text { количе- } \\
\text { ство де- } \\
\text { ревьев }\end{array}$} & \multicolumn{10}{|c|}{ Количество деревьев по ранговым классам высот, (шт./\%) } \\
\hline & & i & $\bar{c}$ & $\frac{m}{\stackrel{1}{\simeq}}$ & $\frac{n}{\dot{J}}$ & $\frac{1}{b}$ & $\frac{a}{\infty}$ & $\overrightarrow{\widehat{\hat{~}}}$ & $\begin{array}{l}\stackrel{\text { I }}{\text { Uे }} \\
\text { }\end{array}$ & $\begin{array}{l}\stackrel{2}{\sim} \\
\stackrel{+}{d}\end{array}$ & స̂̀ \\
\hline $\begin{array}{c}\text { Acer } \\
\text { platanoides L. } \\
\text { (первая пробная } \\
\text { площадка) }\end{array}$ & 40 & $3 / 7,5$ & $4 / 10,0$ & $8 / 20,0$ & $9 / 22,5$ & $10 / 25,0$ & $2 / 5,0$ & $0 / 0$ & $3 / 7,5$ & $0 / 0$ & $1 / 2,5$ \\
\hline \multirow[b]{2}{*}{ Название породы } & Общее & \multicolumn{10}{|c|}{ Количество деревьев по ранговым классам высот, (шт./\%) } \\
\hline & $\begin{array}{l}\text { количе- } \\
\text { ство де- } \\
\text { ревьев }\end{array}$ & $\hat{a}$ & $\vec{\exists}$ & $\frac{m}{\stackrel{1}{c}}$ & $\frac{n}{d}$ & $\frac{1}{b}$ & $\infty$ & 9 & ণิ & $\vec{\sim}$ & ส \\
\hline $\begin{array}{c}\text { Acer } \\
\text { platanoides L. } \\
\text { (вторая пробная } \\
\text { площадка) }\end{array}$ & 50 & $2 / 4,0$ & $5 / 10,0$ & $13 / 26,0$ & $15 / 30,0$ & $8 / 16,0$ & $1 / 2,0$ & $1 / 2,0$ & $1 / 2,0$ & $2 / 4,0$ & $2 / 4,0$ \\
\hline
\end{tabular}

*обственные вычисления авторов 
Таблица 2

Количественное соотношение деревьев дуба черешчатого (Quercus robur L.) по ранговым классам высот в полезащитной полосе

\begin{tabular}{|c|c|c|c|c|c|c|c|c|c|c|c|}
\hline \multirow[b]{2}{*}{ Название породы } & \multirow{2}{*}{$\begin{array}{c}\text { Общее } \\
\text { коли- } \\
\text { чество } \\
\text { деревьев }\end{array}$} & \multicolumn{10}{|c|}{ Количество деревьев по ранговым классам высот (м), (шт./\%) } \\
\hline & & ì & $\stackrel{m}{\stackrel{m}{\sim}}$ & $\frac{n}{7}$ & $\frac{1}{b}$ & $\frac{a}{1}$ & ָे & $\begin{array}{l}\stackrel{\sim}{N} \\
\stackrel{\sim}{N}\end{array}$ & 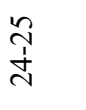 & స̃ & $\begin{array}{l}\text { సे } \\
\infty \\
\text { ஸे }\end{array}$ \\
\hline $\begin{array}{c}\text { Quercus robur L. } \\
\text { (первая пробная } \\
\text { площадка) }\end{array}$ & 42 & $1 / 2,4$ & $0 / 0$ & $0 / 0$ & $2 / 4,8$ & $6 / 14,3$ & $4 / 9,5$ & $4 / 9,5$ & $9 / 21,4$ & $15 / 35,7$ & $1 / 2,4$ \\
\hline & & \multicolumn{10}{|c|}{ Количество деревьев по ранговым классам высот, (шт./\%) } \\
\hline \multirow{2}{*}{$\begin{array}{l}\text { Quercus robur L. } \\
\text { (вторая пробная } \\
\text { площадка) }\end{array}$} & \multirow[t]{2}{*}{32} & $\hat{b}$ & $\overline{1}$ & $\frac{m}{\stackrel{m}{c}}$ & $\frac{n}{\dot{y}}$ & $\frac{1}{b}$ & $\frac{\infty}{\infty}$ & సৃ. & $\begin{array}{c}\text { ָे } \\
\text { ป̀ }\end{array}$ & $\stackrel{\stackrel{2}{\sim}}{\stackrel{\sim}{\sim}}$ & స̃ \\
\hline & & $1 / 3,1$ & $0 / 0$ & $1 / 3,1$ & $5 / 15,6$ & $17 / 53,2$ & $1 / 3,1$ & $1 / 3,1$ & $2 / 6,3$ & $1 / 3,1$ & $3 / 9,4$ \\
\hline
\end{tabular}

* собственные вычисления автора

Первая пробная площадка

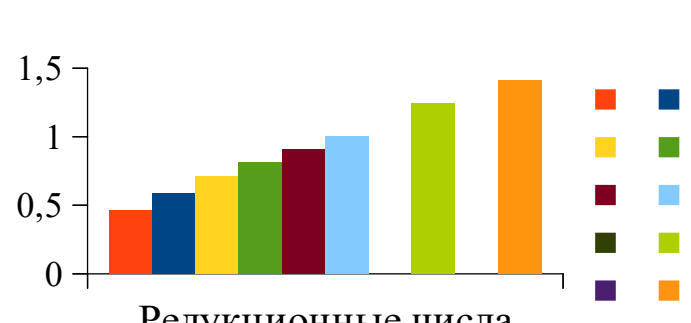

Редукционные числа

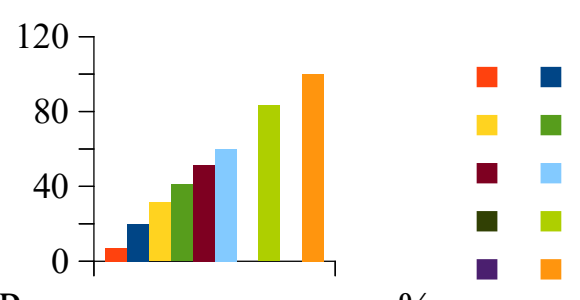

Редукционные ранги, \%

Вторая пробная площадка

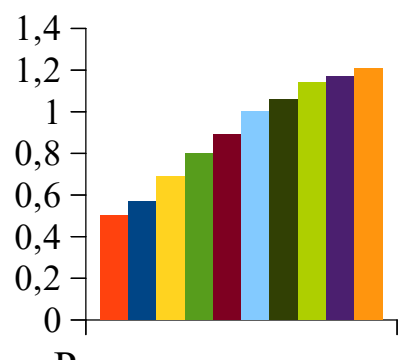

Редукционные числа

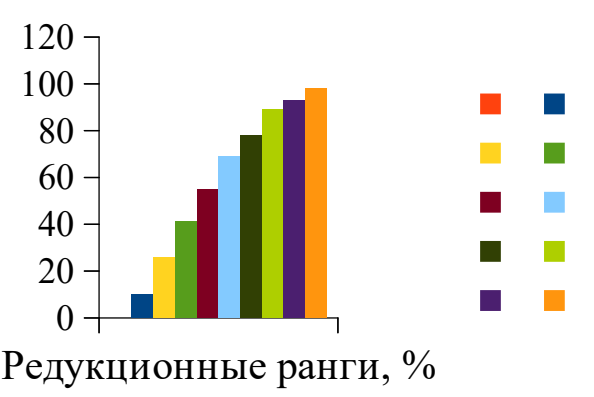

Рис. 1. Редукционные числа и ранги древостоя клёна остролистного (Acer platanoides L.) по высоте на первой (1а) и второй пробной площадке (1б)

*собственные вычисления автора

Древостой клёна остролистного (Acer platanoides L.) на первой пробной площадке характеризуется преобладанием ранговых классов с редукционными числами от 0,46 до 0,91 , что составляет $90 \%$ от общего количества деревьев (рис. 1а). На долю средних и крупных деревьев в ранжированном ряду по высоте приходятся остальные $10 \%$. Это свидетельствует о том, что деревья указанной породы на первой пробной

Лесотехнический журнал 1/2020 площадке достаточно густо расположены друг к другу, составляя конкуренцию за почвенное питание и свет. Редукционному числу со значением единица соответствует средний ранг дерева в ранжированном ряду по высоте с рангом 59,89\% и средней высотой рангового класса 18,2 м. Разница между ранговым классом с редукционным числом единица и последующим составляет 0,1 . 
Наибольшее перераспределение ранговых мест в древостое клёна остролистного (Acer platanoides L.) по высоте наблюдается на второй пробной площадке. На ней произрастают деревья с редукционными числами от 0,50 до 1,21 (рис. 1б). Доля крупных деревьев с редукционным числом от 1,06 до 1,21 составила $12 \%$ от общего количества деревьев, а доля мелких деревьев с редукционным числом от 0,50 до $0,89-86 \%$. Среднее значение находится в $50 \%$ от самого низкого дерева и в $40 \%$ от самого высокого. Редукционному числу со значением единица соответствует средний ранг дерева в ранжированном ряду по высоте с рангом 69,0 \% и средней высотой рангового класса 18,0 м. Это значение на 1,13 \% больше и на 1,25 \% меньше ранга среднего дерева по отношению к деревьям с высотой рангового класса 16,1 м и 19,1 м соответственно.

В древостое дуба черешчатого (Quercus robur L.) на второй пробной площадке разброс редукционных чисел составляет от 0,42 до 1,58 , но отсутствуют деревья в ранговых классах с высотой от 8 до 9 м и от 10 до 11 м (рис. 2). Доля крупных деревьев с редукционным числом от 1,10 до 1,58 и доля мелких деревьев с редукционным числом от 0,42 до 0,89 составляет примерно одинаковое количество - 22 и 25 \% соответственно. На долю средних деревьев с редукционным числом 1 приходится $53 \%$. Среднее значение находится в $40 \%$ от самого низкого дерева и в $50 \%$ от самого высокого. Редукционному числу со значением единица соответствует средний ранг дерева в ранжированном ряду по высоте с рангом 48,3\% и средней высотой рангового класса 16,66 м. Это значение на 1,16 \% больше и на 1,22 \% меньше ранга среднего дерева по отношению к деревьям с высотой рангового класса 14,9 м $\quad$ и 18,2 м соответственно.

Показатель $\Delta \mathrm{R}_{\mathrm{h}}$ показывает вариативность значений высот в ранжированном ряду. Чем больше значение указанного показателя для насаждения, тем больше варьируются высоты в данном древостое, что может свидетельствовать также о наличии второго яруса в древостое. Согласно Л.В. Стоноженко, простым древостоям свойственны наименьшие значения $\Delta \mathrm{R}_{\mathrm{h}}$, а сложным - наибольшие.

Нами в полезащитной полосе для древостоев, образованных из клёна остролистного (Acer platanoides L.) и дуба черешчатого (Quercus robur L.), установлены следующие значения показателя строения древостоя по высоте $\left(\Delta \mathrm{R}_{\mathrm{h}}\right)$ : 0,$95 ; 0,69 ; 0,59 ; 1,13$ (табл. 3). При этом на первой пробной площадке $\Delta \mathrm{R}_{\mathrm{h}}$ для древостоя клёна остролистного он составляет 0,95 , а для дуба черешчатого - 0,59, а на второй пробной площадке эти значения составляют 0,69 и 1,13 соответственно. Следовательно, при формировании второго яруса в древостое из клёна остролистного на первой пробной площадке происходит ухудшение роста и развития дуба черешчатого и, как конечный результат, его разреживание. И наоборот, при упрощении древостоя клёна остролистного на второй пробной площадке происходит улучшение роста и развития дуба черешчатого и, как следствие, усложнение формы насаждения.
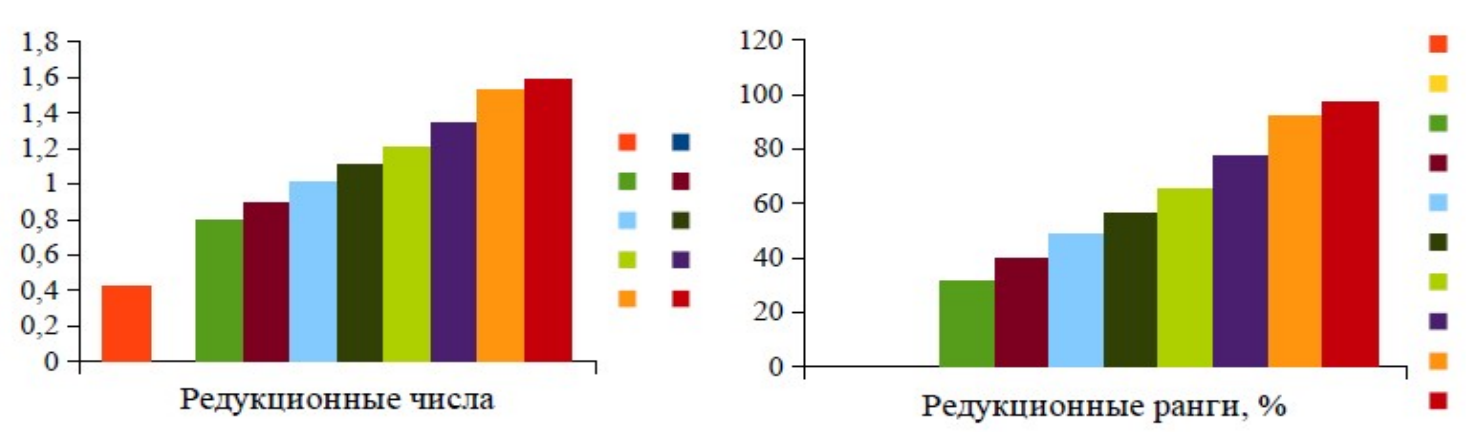

Рис. 2. Редукционные числа и ранги древостоя дуба черешчатого (Quercus robur L.) по высоте на второй пробной площадке

* собственные вычисления автора 
Таблица 3

Показатель строения древостоя по высоте $\left(\Delta \mathrm{R}_{\mathrm{h}}\right)$ полезащитной полосы в окрестностях с. Золотарёвка

\begin{tabular}{|c|c|c|}
\hline Название древесной породы & № пробной площадки & $\Delta \mathrm{Rh}$ \\
\hline Acer platanoides L. & 1 & 0,95 \\
\hline Acer platanoides L. & 2 & 0,69 \\
\hline Quercus robur L. & 1 & 0,59 \\
\hline Quercus robur L. & 2 & 1,13 \\
\hline
\end{tabular}

В целом же для полезащитной полосы в окрестностях с. Золотарёвка (Станично-Луганский район) характерно сложное строение древостоя по форме.

\section{Выводы}

По результатам исследования полезащитной полосы с участием дуба черешчатого (Quercus robur L.) и клёна остролистного (Acer platanoides L.), расположенной в окрестностях с. Золотарёвка Станично-Луганского района Луганской области (Украина), сделаны следующие выводы:

1. Для насаждений указанного района исследования впервые за 35 лет проведено обследование лесополос. Установлено, что в схемах смешения из дуба черешчатого и клёна остролистного при посадке дуба черешчатого во внутренних рядах лесополосы и без прореживания клёна остролистного в крайних рядах происходит ухудшение развития дуба черешчатого и, как следствие, замедление его роста и искривление стволов.

2. Древостой клёна остролистного (Acer platanoides L.) на первой пробной площадке характеризуется преобладанием ранговых классов с редукционными числами от 0,46 до 0,91 , что составляет $90 \%$ от общего количества деревьев. Редукционному числу со значением единица соответствует средний ранг дерева в ранжированном ряду по высоте с рангом 59,89 \% и средней высотой рангового класса 18,2 м.

3. Наибольшее перераспределение ранговых мест в древостое клёна остролистного (Acer platanoides L.) по высоте наблюдается на второй пробной площадке. На ней произрастают деревья с редукционными числами от 0,50 до 1,21 . Редукционному числу со значением единица соответствует средний ранг дерева в ранжированном ряду по высоте с рангом 69,0 \% и средней высотой рангового класса 18,0 м.

4. В древостое дуба черешчатого (Quercus robur L.) на второй пробной площадке разброс редукционных чисел составляет от 0,42 до 1,58 , но отсутствуют деревья в ранговых классах с высотой от 8 до 9 м и от 10 до 11 м. Редукционному числу со значением единица соответствует средний ранг дерева в ранжированном ряду по высоте с рангом 48,3 \% и средней высотой рангового класса 16,66 м.

5. В полезащитной полосе для древостоев, образованных из клёна остролистного (Acer platanoides L.) и дуба черешчатого (Quercus robur L.), установлены следующие значения показателя строения древостоя по высоте $\left(\Delta \mathrm{R}_{\mathrm{h}}\right)$ : 0,95; 0,69; 0,$59 ; 1,13$, что соответствует сложному насаждению.

\section{Библиографический список}

1. Анучин, Н. П. Лесная таксация: учеб. для вузов / Н. П. Анучин. - 5-е изд., доп. - Москва : Лесная промышленность, 1982. - 552 с. - URL: https:/www.booksite.ru/fulltext/rusles/anuchin/1.pdf (дата обращения: 22.09.2019).

2. Багинский, В. Ф. Особенности строения древостоев ольхи в лесах Беларуси / В. Ф. Багинский, Н. Н. Катков, Е. А. Усс // Науковий вісник Національного університету біоресурсів і природокористування Украіни. - 2017. - Сер. Лісівництво та декоративне садівництво. - Вип. 266. - С. 9-15. 
3. Берлин, Н. Г. Биопродуктивность полезащитных лесных полос с дубом черешчатым на чернозёме южном степи Саратовского Правобережья : специальность 06.03.03 «Агролесомелиорация, защитное лесоразведение и озеленение населённых пунктов, лесные пожары и борьба с ними» : автореф. дис. ... канд. с.-х. наук / Берлин Николай Геннадиевич; Сарат. гос. аграр. ун-т им. Н.И. Вавилова. - Саратов, 2015. - 22 с.

4. Высоцкий, К. К. Закономерности строения смешанных древостоев / К. К. Высоцкий. - Москва, 1962. $178 \mathrm{c}$.

5. Грибачева, О. В. Современное состояние полезащитной полосы с участием дуба черешчатого (Quercus robur L.) и клёна остролистного (Acer platanoides L.) / О. В. Грибачева //Лесной журнал. - 2019. - № 4. C. 34-44. - DOI: 10.17238/issn0536-1036.2019.4.34.

6. Доспехов, Б. А. Методика полевого опыта (с основами статистической обработки результатов исследования) / Б. А. Доспехов. - 5-е изд., перераб. и доп. - Москва : Агропромиздат, 1985. - 351 с. - Библиогр.: c. 320-340. - ISBN 978-5-903034-96-3.

7. Зиганшин, Р. А. Закономерности строения древостоев Сибири и их инвентаризация на природной основе : специальность 06.03.02 «Лесоведение, лесоводство, лесоустройство и лесная таксация» : дис. ... д-ра c.-х. наук: защищена 25.05.2000 / Зиганшин Рашид Асхатьевич; Институт леса им. В.Н. Сукачева СО РАН. Красноярск, 2000. - 391 с. - Библиогр.: с. 200-216.

8. Коротков, С. А. Особенности формирования ельников в условиях антропогенного стресса (на примере лесов Клинско-Дмитровской гряды) : специальность 03.00.16 «Экология» : автореф. дис. ... канд. биол. наук / Коротков Сергей Александрович; Московский государственный университет леса. - Москва, 1998. - 24 с.

9. Кузьмичев, В. В. Закономерности динамики древостоев: принципы и модели / В. В. Кузьмичев; Рос. акад. наук СО, Ин-т леса им. В. Н. Сукачева. - Новосибирск : Наука, 2013. - 207 с. - Библиогр: с. 211-215. ISBN 978-5-02-0119148-8.

10. Лепехин, А. А. К оценке роста и лесопатологического состояния дуба после изреживания полезащитных лесополос рубками ухода / А. А. Лепехин // Лесной журнал. - 1987. - № 4. - C. 16-20. - DOI: 10.17238/issn0536-1036.2018.6.70.

11. Наквасина, Е. Н. Динамика рангового распределения деревьев по высоте в потомстве климатипов сосны обыкновенной / Е. Н. Наквасина // Лесной журнал. - 2002. - № 5. - С. 24-29. - URL: https://cyberleninka.ru/article/v/dinamika-rangovogo-raspredeleniya-dereviev-po-vysote-v-potomstve-klimatipovsosny-obyknovennoy.pdf (дата обращения: 18.09.2019).

12. ОСТ 56-69-83 Пробные площади лесоустроительные. Метод закладки. - Москва : ЦБНТИлесхоз, 1984. $-50 \mathrm{c}$.

13. Раменский, Л. Г. Введение в комплексное почвенно-геоботаническое исследование земель / Л. Г. Раменский. - Москва : Сельхозгиз, 1938. -620 с.

14. Сауткина, М. Ю. Современное состояние полезащитных полос с преобладанием дуба черешчатого (Quercus robur L.) в Каменной Степи / М. Ю. Сауткина, Н. Ф. Кузнецова, В. Д. Тунякин // Лесохозяйственная информация: электрон. сетевой журнал. - 2018. - № 1. - С. 78-89. - DOI: 10.24419/LHI.2304-3083.2018.1.07.

15. Стоноженко, Л. В. Исследование строения и формы насаждений / Л. В. Стоноженко, Е. В. Найденова, С. А. Роганова // Лесной вестник. - 2016. - № 5. - С. 205-214. - URL: https://cyberleninka.ru/ article/v/issledovanie-stroeniya-i-formy-nasazhdeniy.pdf (дата обращения: 18.09.2019).

16. Турусов, В. И. Опыт лесной мелиорации степных ландшафтов (к 125-летию «Особой экспедиции... В.В. Докучаева) : моногр. / В. И. Турусов, А. А. Лепехин, А. С. Чеканышкин. - Воронеж : Истоки, 2017. 228 с. - Библиогр.: с. 119-126. - ISBN 978-5-4473-0158-3.

17. Агроэкологическая роль лесных полос в преобразовании ландшафтов (на примере Каменной Степи): моногр. / В. И. Турусов, А. С. Чеканышкин, В. В. Тищенко [и др.] ; Типография Россельхозакадемии. - Москва, 2012. - 191 с. - Библиогр.: с. 110-150. - ISBN 978-5-85941-444-4. 
18. Чеканышкин, А. С. Состояние защитного лесоразведения в Центрально-Черноземной зоне полос / А. С. Чеканышкин, А. А. Лепехин // Лесной журнал. - 2015. - № 4. - С. 9-17. - ISSN 0536-1036.

19. Bao, Y. Effect of Shelterbelts on Winter Wheat Yields in Sanded Farmland of North-Western Shandong Province / Y. Bao, H. Li, H. Zhao // Journal of Food, Agriculture and Environment. - 2012. - No. 10 (3-4). P. 1399-1403.

20. Burke, S. The effect of shelterbelts on crop yields at Rutherglen, Victoria / S. Burke // A National Australian Conference on The Role of Trees in Sustainable Agriculture held at Albury, Victoria, Australia : Proceedings. - Albury, 1991. - P. 89-99.

21. Coates, K. D. Tree recruitment in gaps of various size, clearcuts and undisturbed mixed forest of interior British Columbia, Canada / K. D. Coates // Forest Ecology and Hanagement. - 2002 . - № 155. - P. 387-398.

22. Tree-crop interactions: a physiological approach / ed. by P. Huxley. - CAB International, Wallingford. P. 159-187.

23. Jackson, J. E. Tree and crop selection and management to optimize overall system productivity especially light utilisation in agroforestry / J. E. Jackson // Meteorology and Agroforestry / eds. W. S. Reifsnyder, T. O. Darnhofer. - 1989. - P. 163-173.

24. Magnussen, S. Tree size, biomass and volume growth of twelve 34-year old Ontario jack pine provenances / S. Magnussen, V. G. Smith, C. W. Yeatman // Canadian Journal of Forest Research. - 1985. - Vol. 15. - № 6. P. 1129-1136.

\section{References}

1. Anuchin N.P. Lesnaya taksatsiya: uchebnik dlya vuzov [Forest inventory: textbook]. $5^{\text {th }}$ ed., dop. Moscow: Lesnaya promyshlennost, 1982. 552 p. (in Russian).

2. Baginskij V.F., Katkov N.N., Uss E.A. (2017) Osobennosti stroeniya drevostoev ol'hi v lesah Belarusi [Structural features of alder stands in the forests of Belarus ]. Naukovij visnik Nacional'nogo universitetu bioresursiv $i$ prirodokoristuvannya Ukraini [Scientific Bulletin of the National University of bioresources and nature management of Ukraine], ser. forestry and ornamental gardening, vol. 266, pp. 9-15 (in Russian).

3. Berlin N.G. Bioproduktivnost' polezashchitnyh lesnyh polos s dubom chereshchatym na chernozyome yuzhnom stepi Saratovskogo Pravoberezh'ya: special'nost' 06.03.03: «Agrolesomelioraciya, zashchitnoe lesorazvedenie i ozelenenie naselyonnyh punktov, lesnye pozhary i bor'ba s nimi»: avtoref. dis. ... kand. s.-h. nauk [PhD thesis abstr.], Saratov, 2015. 22 p. (in Russian).

4. Vysotskiy K.K. Zakonomernosti stroeniya smeshannyh drevostoev. Moscow, 1962. 178 p. (in Russian).

5. Gribacheva O.V. (2019) Sovremennoe sostoyanie polezashchitnoj polosy s uchastiem duba chereshchatogo (Quercus robur L.) i klyona ostrolistnogo (Acer platanoides L.) [The current state of the shelterbelt featuring English oak (Quercus robur L.) and Norway maple (Acer platanoides L.)]. Lesnoj zhurnal [Forest Sib], no. 4, pp. 34-44. doi: 10.17238/issn0536-1036.2019.4.34.

6. Dospehov B.A. Metodika polevogo opyta (s osnovami statisticheskoj obrabotki rezul'tatov issledovanija). 5th ed., proc. and complem. Moscow: Agropromizdat, 1985. 351 p. ISBN 978-5-903034-96-3 (in Russian).

7. Ziganshin R.A. Zakonomernosti stroeniya drevostoev Sibiri $i$ ih inventarizaciya na prirodnoj osnove [Regularities of the structure of forest stands in Siberia and their inventory on a natural basis]: 06.03.02 «Lesovedenie, lesovodstvo, lesoustrojstvo i lesnaya taksaciya»: diss. ... DSc (Agriculture) [Doct. thesis]. Krasnoyarsk: Institut lesa im. V. N. Sukacheva SO RAN, 2000. 391 p. (in Russian).

8. Korotkov S.A. Osobennosti formirovaniya elnikov v usloviyah antropogennogo stressa (na primere lesov Klinsko-Dmitrovskoy gryady): 03.00.16: «Ekologiya»: avtoref. dis. ... kand. biol. nauk [PhD (Biology) thesis abstr.]. Moscow: Moskovskij gosudarstvennyj universitet lesa, 1998. 24 p. (in Russian). 
9. Kuz'michev V.V. Zakonomernosti dinamiki drevostoev: principy i modeli [Conformities to law of dynamics of stands: principles and models]. Novosibirsk, Nauka, 2013. 207 p. ISBN 978-5-02-0119148-8 (in Russian).

10. Lepekhin A.A. (1987) $K$ ocenke rosta $i$ lesopatologicheskogo sostoyaniya duba posle izrezhivaniya polezashchitnyh lesopolos rubkami uhoda [To the assessment of growth and forest pathology condition of oak after thinning of shelter belts thinnings]. Lesnoj zhurnal [Forest Sib], no. 4, pp. 16-20. doi: 10.17238/issn05361036.2018.6.70 (in Russian).

11. Nakvasina E.N. (2002) Dinamika rangovogo raspredeleniya derev'ev po vysote v potomstve klimatipov sosny obyknovennoj [Dynamics of the rank distribution of trees in height in the offspring of Scots pine climatypes]. Lesnoj zhurnal [Forest Sib], no. 5, pp. 24-29. URL: https://cyberleninka.ru/article/v/dinamika-rangovogo-raspredeleniyadereviev-po-vysote-v-potomstve-klimatipov-sosny-obyknovennoy. pdf (date of access: 18.09.2019) (in Russian).

12. OST 56-69-83 Probnye ploshshadi lesoustroitelnye. Metod zakladki. V., TsBNTI leshoz, 1984. 50 p. (in Russian).

13. Ramenskiy L.G. Vvedenie v kompleksnoe pochvenno-geobotanicheskoe issledovanie zemel. M.: Selhozgiz, 1938. 620 p. (in Russian).

14. Sautkina M.Yu. (2018) Sovremennoe sostojanie polezashhitnyh polos s preobladaniem duba chereshchatogo (Quercus robur L.) v Kamennoj Stepi [Modern state of the field bands with a predominance of English oak (Quercus robur L.) in Kamennaya Steppe]. Lesohoz. inform. [Forestry Inform.], no. 1. pp. 78-89. doi:10.24419/LHI.23043083.2018.1.07 (in Russian).

15. Stonozhenko L.V., Najdenova E.V., Roganova S.A. (2016) Issledovanie stroenija i formy nasazhdenij [Study of the structure and shape of plantations]. Lesnoj vestnik [Forest Bulletin], no. 5. pp. 205-214. URL: https://cyberleninka.ru/article/v/issledovanie-stroeniya-i-formy-nasazhdeniy.pdf (date of access: 18.09.2019) (in Russian).

16. Turusov V.I., Lepehin A.A., Chekanyshkin A.S. Opyt lesnoj melioracii stepnyh landshaftov (k 125-letiju «Osoboj jekspedicii...» V.V. Dokuchaeva) [Experience of forest reclamation of steppe landscapes (to the 125th anniversary of "Special expedition..." of V.V. Dokuchaev) ].Voronezh: «Istoki», 2017. 228 p. ISBN 978-5-4473-0158-3 (in Russian).

17. Turusov V.I., Chekanyshkin A.S., Tishhenko V.V. (et al.) Agrojekologicheskaja rol' lesnyh polos v preobrazovanii landshaftov (na primere Kamennoj Stepi) [Agro-ecological role of forest belts in the transformation of landscapes]. Moscow: Tipografija Rossel'hozakademii, 2012. 191 p. ISBN 978-5-85941-444-4 (in Russian).

18. Chekanyshkin A.S., Lepehin A.A. (2015) Sostojanie zashhitnogo lesorazvedenija v Central'noChernozemnoj zone polos [The state of the protective afforestation in the Central Chernozem zone]. Lesnoj zhurnal [Forest. Sib], no. 4, pp. 9-17 (in Russian). ISSN 0536-1036.

19. Bao Y., Li H., Zhao H. (2012) Effect of Shelterbelts on Winter Wheat Yields in Sanded Farmland of NorthWestern Shandong Province. Journal of Food, Agriculture and Environment, 10(3-4), pp. 1399-1403.

20. Burke S. (1991) The effect of shelterbelts on crop yields at Rutherglen, Victoria. In: Proceedings from A National Australian Conference on The Role of Trees in Sustainable Agriculture held at Albury, Victoria, Australia. pp. 89-99.

21. Coates K.D. (2002) Tree recruitment in gaps of various size, clearcuts and undisturbed mixed forest of interior British Columbia, Canada. Forest Ecology and Hanagement. № 155, pp. 387-398.

22. Huxley P. (ed.) Tree-crop interactions: a. physiological approach. CAB International, Wallingford, pp. 159-187.

23. Jackson J.E. (1989) Tree and crop selection and management to optimize overall system productivity especially light utilisation in agroforestry. In: Reifsnyder W.S. and Darnhofer T.O. (eds) Meteorology and Agroforestry, pp. 163-173.

24. Magnussen S., Smith V.G., Yeatman C.W. Tree size, biomass and volume growth of twelve 34-year old Ontario jack pine provenances. Canad. Journ. of Forest Research. 1985. Vol. 15. № 6. P. 1129-1136. 


\section{Природопользование}

Сведения об авторах
Грибачева Олеся Владимировна - кандидат биологических наук, доцент, заведующая кафедры плодоовощеводства и лесоводства ГОУ ЛНР «Луганский национальный аграрный университет», г. Луганск, Луганская Народная Республика; e-mail: olesya_kopaneva_78@mail.ua.

Чернодубов Алексей Иванович - доктор сельскохозяйственных наук, профессор кафедры лесных культур, селекции и лесомелиорации ФГБОУ ВО «Воронежский государственный лесотехнический университет имени Г.Ф. Морозова», г. Воронеж, Российская Федерация; e-mail:chernodubov2010@yandex.ru.

Сотников Дмитрий Владимирович - старший преподаватель кафедры плодоовощеводства и лесоводства ГОУ ЛНР «Луганский национальный аграрный университет», г. Луганск, Луганская Народная Республика; e-mail: sotnikofd@mail.ru.

\section{Information about authors}

Gribacheva Olesya Vladimirovna - PhD (Biology), Associate Professor, Head of the Department of Forestry and Horticulture of the State Educational Institution of the Lugansk People's Republic "Lugansk National Agrarian University", Lugansk, Lugansk People's Republic; e-mail: olesya_kopaneva_78@mail.ua.

Chernodubov Aleksey Ivanovich - DSc (Agriculture), Professor, Department of Forest Crops, Selection and Forest Reclamation, FSBEI HE "Voronezh State University of Forestry and Technologies named after G.F. Morozov", Voronezh, Russian Federation; e-mail: chernodubov2010@yandex.ru.

Sotnikov Dmitry Vladimirovich - Master's degree student, Senior Lecturer of the Department of Forestry and Horticulture of the State Educational Institution of the Lugansk People's Republic "Lugansk National Agrarian University", Lugansk, Lugansk People's Republic; e-mail: sotnikofd@mail.ru. 